\title{
PEMBUATAN ASAP CAIR SABUT KELAPA SEBAGAI BAHAN PENGAWET KAYU PADA KELOMPOK TANI KELAPA DI DESA KAMANGTA KECAMATAN PINELENG
}

\author{
I Dewe K. Anom \\ Universitas Negeri Manado \\ dewaanom10@gmail.com
}

\begin{abstract}
Abstrak
Sabut kelapa merupakan salah satu material serat alam yang dapat digunakan sebagai serat alternatif dalam pembuatan campuran bahan atau komposit. Potensi serabut kelapa berpeluang besar untuk dikembangkan menjadi produk selain komposit yang dapat dikomersialkan, mengingat Indonesia memiliki bahan baku serabut kelapa yang melimpah. Dari produksi buah kelapa di Indonesia rata-rata 15,5 milyar butir/tahun, dapat diperoleh 1,8 juta ton serat sabut kelapa. Potensi ketersediaan bahan baku serabut kelapa yang jumlahnya cukup besar ini belum dimanfaatkan secara optimal untuk dikembangkan menjadi produk-produk yang memiliki nilai ekonomi tinggi. Tujuan yang ingin dicapai dalam pengabdian kepada masyarakat ini adalah untuk mengolah limbah sabut kelapa menjadi asap cair sebagai bahan pengawet kayu. Metode yang akan dipakai dalam pencapaian tujuan tersebut adalah mitra diberi pelatihan dan praktek sampai mahir cara mengolah limbah sabut kelapa menjadi asap cair sebagai bahan pengawet kayu. Kelompok tani kelapa di Kelurahan Desa Kamangta dapat melakukan cara pembuatan asap cair dari limbah sabut kelapa. Kelompok tani kelapa di Kelurahan Desa Kmangta memberi respon positif terhadap pemanfaatan limbah sabut kelapa menjadi asap cair sebagai salah satu sumber bahan pengawet kayu. Terjalin hubungan yang baik antara Lurah Desa Kamangta dengan pelaksana pengabdian masyarakat dan masyarakat kelompok tani kelapa di kelurahan Desa Kamangta.
\end{abstract}

Kata kunci. Pirolisis, sabut kelapa, pengawet, kayu. 


\section{PENDAHULUAN}

Salah satu jenis limbah bahan alam yang sangat berpotensi untuk dimanfaatkan Salah satu jenis limbah yang sangat berpotensi untuk dimanfaatkan sebagai bahan baku industri pengawet kayu adalah limbah sabut kelapa. Di Sulawesi Utara limbah sabut kelapa sangat melimpah, akan tetapi fungsi dan pemamfaatan masih sangat terbatas, yakni hanya digunakan sebagai tali, sapu dan bahan bakar saja. Permasalahan utama yang menjadi penyebab tidak berkembangnya industri pengolahan sabut kelapa karena kurangnya inovasi dan terbatasnya produk yang dihasilkan. Karena itu industri pengolahan sabut kelapa tersebut tidak mampu meraih pasar yang lebih luas, dianggap tidak prospektif dan kurang menjanjikan bagi masa depannya.

Salah satu upaya strategis yang perlu dilakukan untuk meningkatkan nilai ekonomi limbah sabut kelapa tersebut adalah membangun industri pengolahan limbah sabut kelapa yang dapat menghasilkan produk asap cair. Produk asap cair akan berdampak baik bagi pengambangan limbah sabut kelapa dan juga sangat bermakna dalam pencarian solusi penanganan limbah sabut kelapa menjadi produk-produk unggulan yang bermamfaat. Jika upaya pembuatan asap cair sebagai bahan pengawet kayu dapat dilakukan dengan baik maka diharapkan akan dapat menumbuhkan inovasi-inovasi baru untuk berkreasi mengembangkan produk-produk lokal berbahan baku sabut kelapa yang nantinya dapat diminati oleh masyarakat konsumen.

Pemanfaatan limbah sabut kelapa dalam industri pembuatan asap cair merupakan solusi yang tepat dan strategis karena asap cair sebagai bahan pengawet kayu sangat dibutuhkan oleh konsumen. Kehadiran asap cair dari limbah sabut kelapa ini diharapkan akan mendapat apresiasi pasar yang positif. Hal itu tentu berdampak positif bagi pengembangan pemanfaatan limbah sabut kelapa, sehingga aktivitas produksi asap cair sabut kelapa ini dapat berjalan kontinu. Dari solusi yang ditawarkan, diharapkan minat masyarakat tumbuh untuk menekuni profesi sebagai pengusaha asap cair dari sabut kelapa, karena menjanjikan pekerjaan baru dan penghasilan tetap bagi masa depannya.

\section{BAHAN}

Bahan yang digunakan untuk pembuatan asap cair ini adalah limbah sabut kelapa yang diambil secara acak dari desa Kamangta Kecamatan Pineleng Kabupaten Minahasa.

\section{PERALATAN}

Peralatan yang digunakan untuk pembuatan asap cair ini adalah 1 set alat pirolisis yang terdiri dari reaktor pirolisis yang dilengkapi dengan pipa pengalir asap, 
pendingin air, dan alat penampung asap cair dan timbangan.

\section{PELAKSANAAN KEGIATAN}

Secara umum metode pelaksanaan kegiatan mengacu pada langkah-langkah sebagai berikut:

1. Kegiatan pertama adalah survey keberadaan limbah sabut kelapa akibat proses produksi kelapa di desa Kamangta I Kecamatan Pineleng.

2. Pelatihan kelompok tani tentang cara membuat asap cair dari limbah sabut kelapa.

3. Praktek pirolisis limbah sabut kelapa untuk mendapatkan asap cair.

4. Praktek pembuatan jenis-jenis kemasan dan labeling asap cair sebagai pengawet kayu ukuran 250 $\mathrm{mL}, 500 \mathrm{~mL}, 1000 \mathrm{~mL}$.

5. Kegiatan keempat adalah evaluasi terhadap keberhasilan tiap kegiatan. Jika dalam evaluasi ada indikasi pelaksanaan kegiatan belum mencapai hasil sesuai target minimal yang ditetapkan, maka target yang belum tercapai akan diulang hingga target tercapai.

\section{HASIL DAN PEMBAHASAN}

Kegiatan survey tentang limbah sabut kelapa di desa Kamangta, ternyata limbah sabut kelapa cukup banyak. Hampir semua limbah sabut kelapa tidak diolah oleh petani kelapa dan limbah tersebut dibiarkan saja. Hanya sebagian kecil saja limbah sabut kelapa digunakan sebagai bahan bakar, dan sisanya dibiarkan tidak diolah. Akibat banyaknya limbah sabut kelapa yang tidak diolah menjadi produk yang lebih bermanfaat, maka kelompok tani kelapa desa Kamangta diberi pelatihan tentang cara membuat asap cair dari limbah sabut kelapa. Metode yang diperkenalkan untuk membuat asap cair dari limbah sabut kelapa adalah pirolisis.

Pirolisis limbah sabut kelapa menghasilkan asap cair sebanyak 30\%. Asap cair yang diperoleh berwarna cokelat gelap disajikan pada Gambar 1.

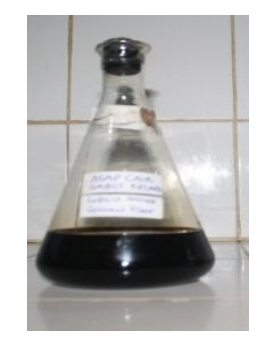

Gambar 1. Warna asap cair dari sabut kelapa

Suhu pirolisisi sabut kelapa sekitar 350 $400^{\circ} \mathrm{C}$. Pada proses pirolisis, tabung pirolisis hanya diisi setengah bagian sabut kelapa, hal ini dilakukan agar semua bahan dalam tabung pirolisis mendapat panas pembakaran yang merata. Setelah 40-50 menit proses pemanasan berlangsung, asap sabut kelapa mulai mengalir menuju pipa kondensor yang dialiri air secara kontinu 
sehingga asap sabut kelapa yang berupa gas dapat dicairkan. Selama proses pirolisis berlangsung ada sebagian kecil asap sabut kelapa tidak dapat dicairkan dan gas tersebut mudah terbakar. Proses pirolisis sabut kelapa dihentikan setelah tidak ada lagi destilat asap cair yang menetes ke dalam wadah penampung.Wijaya, dkk. (2008) menjelaskan bahwa komposisi rendemen yang diperoleh juga sangat tergantung pada sistem kondensasi, hal ini juga dijelaskan oleh Tranggono, dkk. (1997), bahwa pirolisis pada suhu yang terlalu tinggi dan waktu yang terlalu lama akan menyebabkan pembentukan asap cair berkurang karena suhu dalam air pendingin semakin meningkat sehingga asap yang dihasilkan tidak terkondensasi secara optimal. Proses kondensasi akan berlangsung secara optimal apabila air di dalam sistem pendingin dialiri secara kontinu sehingga suhu dalam sistem pendingin tidak meningkat.

Fatimah dan Jaka (2005), menjelaskan pirolisis biomassa merupakan salah satu teknologi alternatif yang dikembangkan pada beberapa bidang kimia. Pada proses pirolisis terhadap kayu, terjadi degradasi lignin sebagai akibat dari kenaikan temperatur sehingga dihasilkan senyawa-senyawa karakteristik sesuai dengan jenis kayu. Fatimah (2004), menjelaskan pirolisis adalah teknologi alternatif sebagai sumber hidrokarbon. Berbagai teknik pirolisis dikembangkan tidak hanya untuk konversi bahan-bahan polimer menjadi hidrokarbon bermanfaat tetapi juga digunakan untuk sintesis hidrokarbon berbahan biomassa atau tumbuhan. Pirolisis sering juga sebagai termolisis secara definisi adalah proses terhadap suatu materi dengan menambahkan aksi temperatur yang tinggi tanpa kehadiran oksigen.

Berdasarkan beberapa penelitian menunjukkan bahwa komponen utama asap cair dapat dikelompokkan menjadi 3 komponen utama yang dominan yaitu fenol, karbonil, asam dan ketiga kelompok senyawa tersebut saling bersinergi sehingga berpotensi bersifat insektisida. Fenol dan turunannya dapat bersifat bakteriostatik maupun bakterisidal karena mampu menginaktifkan enzim-enzim esensial, mengkoagulasi $\mathrm{SH}$ group dan $\mathrm{NH}$ group protein (Karseno, dkk. 2002, dalam Zuraida, 2009). Komponen fonol (fenol, metil fenol dan guaiakol) serta komponen asam (turunan asam benzoate) adalah komponen yang teridentifikasi dalam asap cair tempurung kelapa yang berperan sebagai antibakteri (Zuraida, 2009). Asam dan fenol merupakan komponen utama asap cair yang mempengaruhi mortalitas rayap. Kandungan asam pada asap cair juga efektif dalam mematikan dan menghambat pertumbuhan mikroba pada produk makanan dengan cara senyawa asam itu menembus dinding sel mikroorganime yang menyebabkan sel 
mikroorganisme menjadi lisis kemudian mati. Kresol atau senyawa 2-metoksi-4metil-penol yang terdapat pada asap cair sabut kelapa merupakan salah satu senyawa fenol yang dalam industri untuk membunuh jenis serangga, dan biasa ditambahkan dalam produk pembersih sebagai desinfektan. Bahan asap cair mengandung zat aktif yang berfungsi sebagai antimikroba atau desinfektan dan juga dapat digunakan sebagai insektisida sebagai obat dipping dalam menangani kasus-kasus penyakit pada hewan (Utami, dkk. 2008). Kelompok senyawa karbonil berperan sebagai pemberi aroma untuk produk pangan dan pengusir insekta. Kadar karbonil rata-rata asap cair dari sabut kelapa adalah 10,26\% (Mappiratu, 2009). Asap cair dapat berperan sebagai antimikroba dan antioksidan, maka asap cair dapat digunakan sebagai bahan pengawet, antirayap dan antijamur serta dapat digunakan untuk penggumpalan karet dan pestisida alami (Yuwanti, 2003; Darmadji, 2006 dalam Mappiratu, 2009). Asap cair sabut kelapa mengandung fenol 3,03\%, karbonil 10,26\% dan asam asetat 9,22\%, serta memiliki keasaman $(\mathrm{pH})$ sebesar 3,16 (Mappiratu, 2009).

\section{KESIMPULAN}

1. Kelompok tani kelapa di Kelurahan Desa Kamangta dapat melakukan cara pembuatan asap cair dari limbah sabut kelapa.
2. Kelompok tani kelapa di Kelurahan Desa Kamangta memberi respon positif terhadap pemanfaatan limbah sabut kelapa menjadi asap cair sebagai salah satu sumber bahan pengawet kayu.

3. Terjalin hubungan yang baik antara Lurah Desa Kamangta dengan pelaksana pengabdian masyarakat dan masyarakat kelompok tani kelapa di kelurahan Desa Kamangta.

4. Pirolosis sabut kelapa menghasilkan rendemen asap cair sebesar 30\% dan besarnya rendemen yang diperoleh sangat bergantung pada suhu pirolisis dan sistem kondensasi dari peralatan yang digunakan.

\section{KEPUSTAKAAN}

Aisyah, I., N. Juli, G. Pari. (2012). Pemanfaatan Asap Cair Tempurung Kelapa Untuk Mengendalikan Cendawan Penyebab Penyakit Antraknosa Dan Layu usarium Pada Ketimun. J. Penelitian Hasil Hutan, 31(2), 170-178.

Ayudiarti, D. L., R. N. Sari. (2010). Asap Cair Dan Aplikasinya Pada Produk Perikanan. J. Squalen, 5(3), 101-108.

Alpian, T. A. Prayitno, J. P. G. Sutapa, Bidiadi, 2014. Kualitas Asap Cair Batang Gelam (Melaleuce sp), J. Penelitian Hasil Hutan, 32(2), 83-92.Wijaya, M., E.

Erawati, E., T. W. Kirana, E. Budiyati, W. B. Sediawan, P. Mulyono, 2013. Distilasi Asap Cair Hasil Pirolisis Limbah Serbuk Gergaji 
Kayu Glugu, Simposium Nasional

RAPI XIV-2015 FT UMS, ISSN 1412-9612.

Fatimah, I., N. Jaka. (2005). Identifikasi Hasil

Pirolisis Serbuk Kayu Jati Menggunakan

Principal Component Analysis. J. Ilmu Dasar, 6(1), 41-47.

Mappiratu. (2009). Kajian Teknologi

Produksi Asap Cair Dari Sabut Kelapa. J

Media Litbang Sulteng, 2(2), 104-109.

Noor, T. T. Irawadi, G. Pari. (2008).

Perubahan Suhu Pirolisis Terhadap

Struktur Kimia Asap Cair Dari Serbuk

Gergaji Kayu Pinus. J. Ilmu

dan

Teknologi Hasil Hutan, 1(2), 73-77.

Pari, G., 2002. Teknologi Alternatif

Pemanfaatan Sampah Industri Pengolahan

Kayu, Makalah Falsafah Sains IPPs 70 L)

Program Sarjana/C3 Bogor: Institut Pertanian Bogor.

Pszcola D. C, 1995. Tour Higlights

Production and Uses if Smoke Base Flavor

Food Tech, (49), 70-74

Rismansyah, E. A., 2014. Pengaruh Asap cair

Terhadap Mortalitas Larva Brontispa Longissima di Laboratorium dengan

Metode Food Poisoning, Balai Proteksi Tanaman Perkebunan Pontianak, Analisis Laboratorium Hama, Predator dan Parasitoid

Sahwalita, H. Sanjaya, Nuryana, 2003. Karakteristik Briket Arang dari Limbah

Pembalakan Kayu Eucalyptus grandis. RIMBA Kalimantan Fakultas Kehutanan Unmul, 11(1), 17-20.

Siswanto, M. F., A. Saputra, H. Amrulloh, 2011. Pengaruh Pengawetan Bambu Wulung dengan Asap Cair Tempurung Kelapa Terhadap Mortalitas Rayap Kayu Kering, Dinamika Teknik Sipil, 11 (2), 151-154.

Tranggono, S., B. Setiadji, P. Darmadji, Supranto, Sudarmanto, R. Armunanto. (1997). J. Ilmu dan Teknologi Pangan, 1(2), 15-24.

Utami, A. S. J., A. A. NG. B. S. Dinata, G. Guntoro. (2008). Pemanfaatan Asap Cair Sebagai Obat Scabies Pada Kambing. Seminar Nasional Teknologi Peternakan dan Veteriner. Balai Pengkajian Teknologi Pertanian Bali, Denpasar.

Yulita, E., 2012. Pengaruh Asap Cair Serbuk Kayu Limbah Industri Terhadap Mutu Bokar. J. Riset Industri, 4(1), 13-2

Zuraida, I. (2009). Daya Hambat Asap Cair Tempurung Kelapa Terhadap Bakteri Patogen. J. Teknologi Pertanian, 4(2),

$56-62$. 